\title{
Importance of the Viral Shunt in Nitrogen Cycling in Synechococcus Spp. Growth in Subtropical Western Pacific Coastal Waters
}

\author{
An-Yi Tsai ${ }^{1, *}$, Gwo-Ching Gong ${ }^{1,2,3}$, and Yu-Wen Huang ${ }^{1}$ \\ ${ }^{I}$ Institute of Marine Environmental Chemistry and Ecology, National Taiwan Ocean University, Keelung, \\ Taiwan, Republic of China \\ ${ }^{2}$ Center of Excellence for Marine Bioenvironment and Biotechnology, National Taiwan Ocean University, Keelung, Taiwan, \\ Republic of China \\ ${ }^{3}$ Taiwan Ocean Research Institute, National Applied Research Laboratories, Taipei, Taiwan, Republic of China
}

Received 21 November 2013, revised 22 May 2014, accepted 11 June 2014

\begin{abstract}
Viruses play an important role in aquatic environments in bacteria and phytoplankton mortality and also in carbon and nutrient recycling through the lysis of living cells. However, the effects of nitrogen regenerated by viral lysis on the growth of picophytoplankton are rarely studied. This study investigated whether the presence of viruses has a positive effect on the daytime frequency of cell division in Synechococcus spp. in the coastal waters of the western subtropical Pacific Ocean. Using cell incubation with natural viral loads and reduced virus treatments, we characterized the abundance and frequency of cell division in Synechococcus spp. over time. Our results clearly showed that during the daytime as much as $30 \%$ of Synechococcus spp. were dividing in natural virus-containing samples, a proportion six times that found in the virus-diluted treatment groups (5\%). These results suggest that viruses can exert significant effects on nutrient regeneration, enhancing daytime cell division rates in Synechococcus spp.
\end{abstract}

Key words: Viruses, Mortality, Virus-free, Synechococcus spp., Frequency of dividing cells, Regenerated nitrogen

Citation: Tsai, A. Y., G. C. Gong, and Y.W. Huang, 2014: Importance of the viral shunt in nitrogen cycling in Synechococcus spp. growth in subtropical western Pacific coastal waters. Terr. Atmos. Ocean. Sci., 25, 839-846, doi: 10.3319/TAO.2014.06.11.01(Oc)

\section{INTRODUCTION}

Viruses are an important component in aquatic microbial communities because they are more abundant $\left(10^{9}-10^{10}\right.$ viruses $\left.\mathrm{L}^{-1}\right)$ than picoplankton in these environments where they can easily infect bacteria and phytoplankton (Fuhrman 1999; Hambly and Suttle 2005). Lysed bacterial cells, however, release dissolved organic matter (DOM), which recycles bacterial carbon as bacterial production (Middelboe et al. 1996; Middelboe and Lyck 2002; Wilhelm et al. 2002). Thus, viral lysis may also serve as a significant pathway for the regeneration of nutrients, directly enhancing nutrient supply rates to phytoplankton (Haaber and Middelboe 2009; Weinbauer et al. 2011; Shelford et al. 2012).

The cyanobacteria Synechococcus spp. contribute importantly to phytoplankton abundance and photosynthetic production in the upper layer of coastal and oceanic waters

\footnotetext{
* Corresponding author

E-mail:anyitsai@mail.ntou.edu.tw
}

(Worden et al. 2004; Tsai et al. 2005; Uysal 2006). In oligotrophic oceans, Synechococcus spp. contribute up to $>50 \%$ of the total photosynthetic carbon fixation (Iriarte and Purdie 1994). Furthermore, during warm seasons, Synechococcus spp. shows distinct diel changes in abundance, with higher division rates at dusk (Dolan and Šimek 1999; Christaki et al. 2002; Tsai et al. 2009) and maximum abundances at night (Christaki et al. 2002; Tsai et al. 2008, 2009). Therefore, Synechococcus spp. abundance is less than $1 \times 10^{4}$ cells $\mathrm{mL}^{-1}$ during low temperatures when there are no clear diel variations in abundance (Tsai et al. 2008). Christaki et al. (2002) reported that heterotrophic nanoflagellate (HNF) grazing on Synechococcus spp. is the highest at night and declines during the daytime in oligotrophic open-sea areas. However, during the summer in subtropical western Pacific coastal waters grazing by pigmented nanoflagellates (PNF) appears to be the underlying biological factor regulating diel variations in Synechococcus spp. (Tsai et al. 2009). Much attention has recently been paid to the mortality rates of Synechococcus 
spp. due to viral lysis (Suttle 2000; Wang and Chen 2004; Baudoux et al. 2007, 2008), which has been reported to be especially high at nighttime in the subtropical Pacific Ocean (Tsai et al. 2012).

Specific resources (inorganic nutrients) and temperature are reported to be the main limiters of growth in Synechococcus spp. (Chang et al. 1996; Carlsson and Caron 2001; Tsai et al. 2005), although in warmer seasons the availability of nutrients appears to be the strongest factor (Tsai et al. 2008). Data from nutrient dilution experiments suggest that Synechococcus spp. may depend on locally recycled nutrients (Ayukai 1996). For example, Weinbauer et al. (2011) found that viral-induced ammonium regeneration enhanced Synechococcus spp. growth and increased the proportion of its dividing cells. Weinbauer hypothesized that viral infection may play an important role in $\mathrm{N}$ recycling in the sea. Shelford et al. (2012) found a decrease in ammonium and $\mathrm{Chl} a$ production when they reduced the abundance of viruses in their samples of temperate and tropical seawater, suggesting that viruses are important but neglected agents of ammonium regeneration in a range of marine environments. To date, no study has substantiated the significance of the viral lysis products released from host cells in the subtropical Pacific Ocean. Therefore, using a simplified dilution method, we sought to determine whether viral lysis serves as a significant source of recycled nutrients in the subtropical western Pacific and whether the presence of viruses exerts a positive effect on the daytime frequency of dividing cells (FDC) of Synechococcus spp.

\section{MATERIALS AND METHODS}

\subsection{Sampling}

Samples were collected from the surface waters $(0.5 \mathrm{~m})$ of an established coastal station $\left(25^{\circ} 9.4^{\prime} \mathrm{N}, 121^{\circ} 46.3^{\prime} \mathrm{E}\right)$ along a rocky shore in northeastern Taiwan in August and September 2012 (Fig. 1). The environment at this site was previously described based on data gathered from 1999 - 2001 by Tsai et al. (2005). The surface water temperature is around $16^{\circ} \mathrm{C}$ in March and increases gradually to $29^{\circ} \mathrm{C}$ in July (Tsai et al. 2005). The annual salinity ranges from $33.1-34.3 \%$, with the lower salinity within this range possibly reflecting the influence of rainfall runoff. The average nitrate concentration is highest (up to $12 \mu \mathrm{M}$ ) between November and May, and then decreases to about $1 \mu \mathrm{M}$ in June - October. The Synechococcus spp. abundance has shown a strong diel variation pattern, with the greatest abundance recorded between 2000 - 0000 hours (local time), while FDC decreases to low values (about $<5 \%$ ) during the summer (Tsai et al. 2009). During this study the water temperature was measured immediately after bucket-cast, with all samples brought to the laboratory within $30 \mathrm{~min}$. Ammonium was measured using an improved indophenol blue spectrophotometric method with a precision of $0.05 \mu \mathrm{m}$ (Pai et al. 2001).

\subsection{Incubation Experiments}

The experiments in this study were designed to observe the effects of nutrient cycling by heterotrophic bacteria viral lysis and its subsequent effects on Synechococcus spp. We used a simplified dilution method to compare the two treatments: virus-reduced (VD) treatment prepared with virusfree water and virus existing (VE) treatment with nearly in situ viral abundance.

To prepare the VE treatment the natural sample was passed through a $1.0-\mu \mathrm{m}$ pore-size polycarbonate filter (47-mm diameter) to remove the nanoflagellate grazing pressure and retain bacteria, Synechococcus spp., and viruses. In the VD treatments natural water was serially filtered through 1.0 and $0.2 \mu \mathrm{m}, 47 \mathrm{~mm}$ diameter polycarbonate filters (AMD Manufacturing) operated at low pressure $(<50 \mathrm{~mm}$ $\mathrm{Hg}$ ), with the first filter removing larger picoplankton predators and the second concentrating bacteria and Synechococcus spp. (Wilhelm et al. 2002). This approach resulted in bacteria and Synechococcus spp. abundances similar to in situ abundances. A transfer pipette was used to keep the bacteria and Synechococcus spp. in suspension above the $0.2-\mu \mathrm{m}$ filter (Shelford et al. 2012). One subsample was then $30 \mathrm{kDa}$-filtered to remove viruses and create virus-free water. The VD experiment was prepared by adding $200 \mathrm{~mL}$ of bacterial concentrate to $800 \mathrm{~mL}$ of virus-free water. The mixtures were incubated in triplicate in $1000-\mathrm{mL}$ polycarbonate bottles under natural light in a water bath outside the laboratory. In Exp. 1 samples were collected every 3 hours from 0000 - 1200 in August 2012. In Exp. 2 incubations were subsampled at 0,20, and 44 hours during September 2012. Samples were also collected from in situ surface waters at the same time that incubations were sampled.

\subsection{Virus, Bacteria, and Synechococcus Spp. Abundance Counts}

Viruses, bacteria and Synechococcus spp. were counted using an epifluorescence microscope (Nikon Optiphot-2) at $1000 \times$ magnification. Subsamples for counting bacteria and viruses were put into $10 \mathrm{~mL}$ centrifuge tubes, fixed with glutaraldehyde (final conc. $0.5 \%$ ) and stored at $4{ }^{\circ} \mathrm{C}$ until analysis, a process that was normally completed within one week of sample collection. Viruses were processed using a slight modification of a method described by Noble and Fuhrman (1998). Briefly, samples from $0.5-1 \mathrm{~mL}$ were filtered on Anodisc filters $(0.02-\mu \mathrm{m}$ pore size, Whatman) backed by $0.45 \mu \mathrm{m}$ pore size Millipore filters. Each filter was laid sample side up on a drop of SYBR Green I (Molecular Probes) solution diluted at 1:400 in TE buffer $(10 \mathrm{mM}$ Tris- $\mathrm{HCl}$, $1 \mathrm{mM}$ EDTA, $\mathrm{pH}$ 8.0) for $15 \mathrm{~min}$ in the dark. Membranes were then placed onto glass slides and treated with $25 \mu \mathrm{L}$ of $50 \%$ glycerol and $50 \%$ PBS buffer $(0.85 \% \mathrm{NaCl}, 0.05 \mathrm{M}$ $\mathrm{NaH}_{2} \mathrm{PO}_{4}, \mathrm{pH} 7.5$ ) containing $0.1 \%$ p-phenylenediamine as 
antifade and mounting agents. Subsamples of $1-2$ or $4 \mathrm{~mL}$ were filtered onto $0.2 \mu \mathrm{m}$ black Nuclepore filters to count bacteria and Synechococcus spp., respectively. Samples for counting bacteria were stained with 4'6-diamidino-2phenylindole (DAPI) at a final concentration of $1 \mu \mathrm{g} \mathrm{mL}-1$ (Porter and Feig 1980). These filters were stored at $-20^{\circ} \mathrm{C}$ until counting using an epifluorescence microscope. Bacteria were identified by their blue fluorescence under UV illumination. Synechococcus spp. were identified by their orange auto fluorescence under blue excitation light. Cells undergoing division and having a complete cross wall between daughter cells were also counted. The frequency of cells in division (FDC) was determined by dividing the cells undergoing division by the total number of cells counted (Campbell and Carpenter 1986). To obtain reliable estimates of abundance, at least 1000 virus particles, 800 bacteria, and 200 Synechococcus spp. were counted per sample.

\section{RESULTS}

During the study period time-course data for incubation temperatures varied from $28^{\circ}-29.5^{\circ}$ and $27.5^{\circ}-28.5^{\circ} \mathrm{C}$ in Exps. 1 and 2, respectively. Furthermore, no significant differences were found in bacterial and Synechococcus spp. abundance and FDC between VE and VD treated groups at the start of Exps. 1 and 2 ( $t$-test, $p>0.05$ ) (Figs. 2a, b, 3a, b). Ammonium concentrations were initially indistinguishable in VE and VD for Exp. 1 (Exp. 1: VE $=0.9 \pm 0.02 \mu \mathrm{M}$, $\mathrm{VD}=0.9 \pm 0.05 \mu \mathrm{M}$ ) (Fig. 4b). However, ammonium concentrations at the start of Exp. 2 were significantly less in VD than in VE treatments $(t$-test, $p<0.05$; Exp. 2: $\mathrm{VE}=2.8 \pm 0.08 \mu \mathrm{M}, \mathrm{VD}=2.4 \pm 0.05 \mu \mathrm{M}$ ) (Fig. 5b). Moreover, in this study there was a significantly lower viral abundance in the VD treatment than the VE treatment at the beginning of Exps. 1 and 2 (72 and 65\% decrease, $t$-test, $p<0.05$ ) (Figs. 2c, 3c). These findings showed that dilution with a $30 \mathrm{kDa}$ filtrate successfully reduced the abundance of viruses.

Experiment 1 samples displayed significant decreases in Synechococcus spp. and bacterial abundances during the nighttime VE treatment (Figs. 2a, b). At the same time there were significantly greater increases in viral abundance in VE than in VD treatments during Exp. 1 (Fig. 2c; $t$-test, $p<0.05$ ). There were temporal changes in the FDC of Synechococcus spp. and ammonium concentrations over 12 hours in Exp. 1 (Fig. 4). We found that up to $30 \%$ of Synechococcus spp. were dividing in the VE treatment during the daytime, a proportion six times that of the VD treatment (about 5\%) (t-test, $p<0.05)$ (Fig. 4a).

We performed Exp. 2 to confirm the FDC trend found in VE and VD treatments. Experiment 2 lasted for 2 days with the purpose of obtaining samples at time points previously identified as have high FDC values. As expected, the average value of FDC was $17 \%$ in the VE treatment and $3.6 \%$ in the VD treatment, with significant differences between the two treatments on the first day of sampling (4-September) ( $t$-test, $p<0.05)$ (Fig. 5a). At the final sampling point (5 September), we did not observe FDC cells in the VD treatment, but FDC values remained high in the VE treatment (38.7\%) (Fig. 5a). At the end of Exp. 2, the abundance of Synechococcus spp. was $4.8 \times 10^{4}$ cells $\mathrm{mL}^{-1}$ in the VE treatment, which was 10 times that of the VD treatment $\left(0.5 \times 10^{4}\right.$ cells $\left.\mathrm{mL}^{-1}\right)$ (Fig. 3a). Furthermore, we also found that bacterial abundance was significantly lower in the VD than the VE treatment or the in situ seawater at the final sampling point (5 September) (ANOVA, $p<0.05)$ (Fig. 3b). Together these findings indicate that viruses significantly affect variations in Synechococcus spp. and bacterial abundances

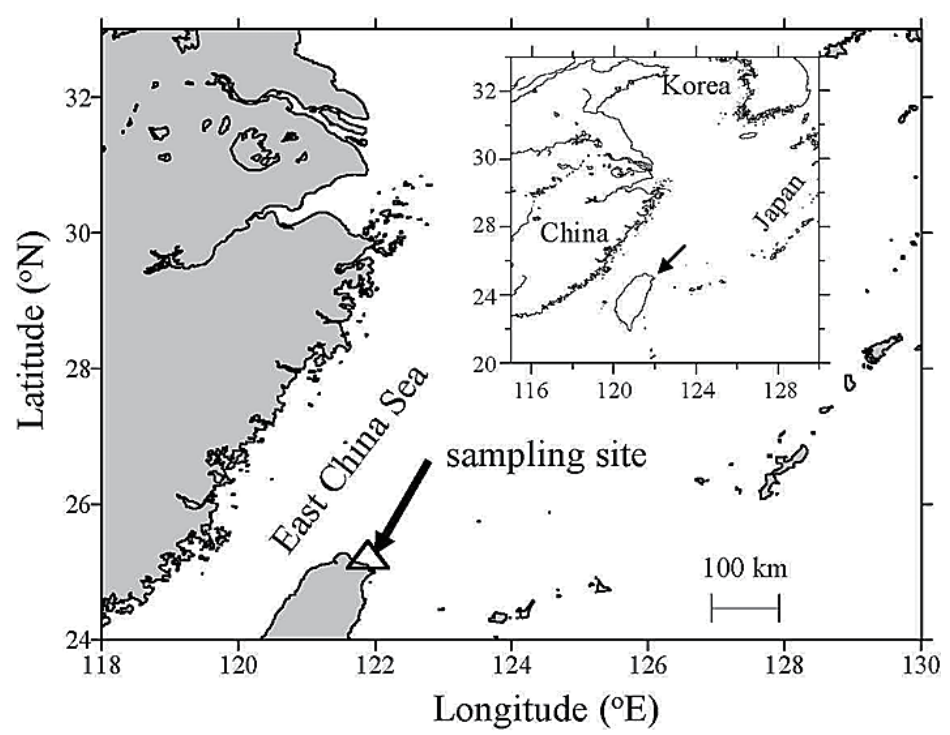

Fig. 1. Location of the sampling site in coastal waters of the western subtropical Pacific. 

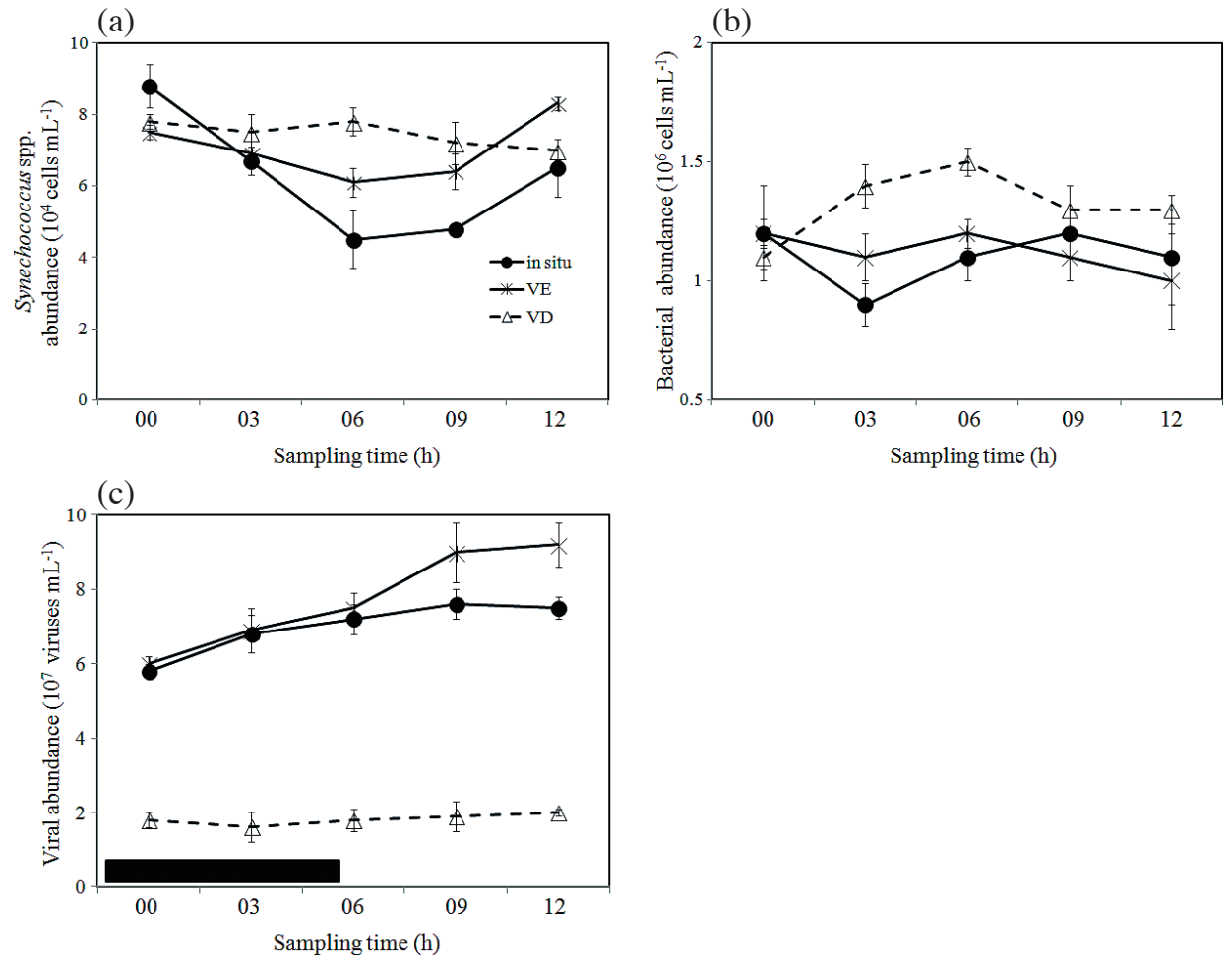

Fig. 2. Time-series of Synechococcus spp. (a), bacterial (b), and viral (c) abundances in in situ seawater and virus-existing (VE) and virus-diluted samples (VD). The filled black bar represents nighttime.

(a)

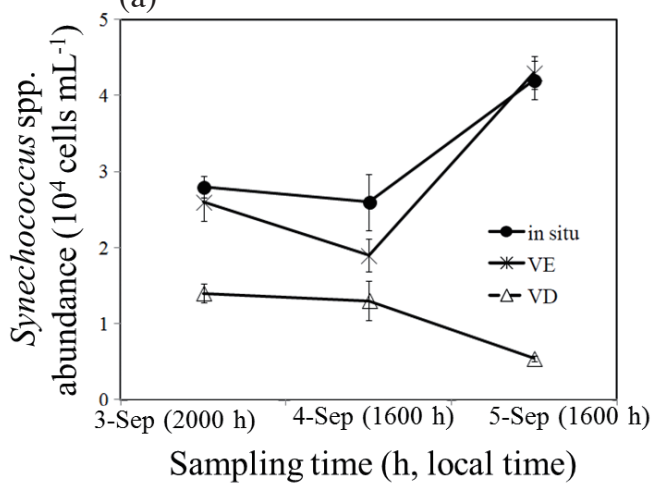

(c)

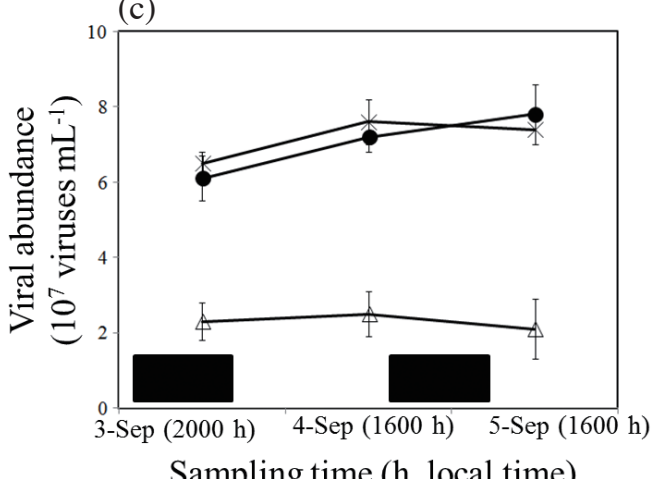

(b)

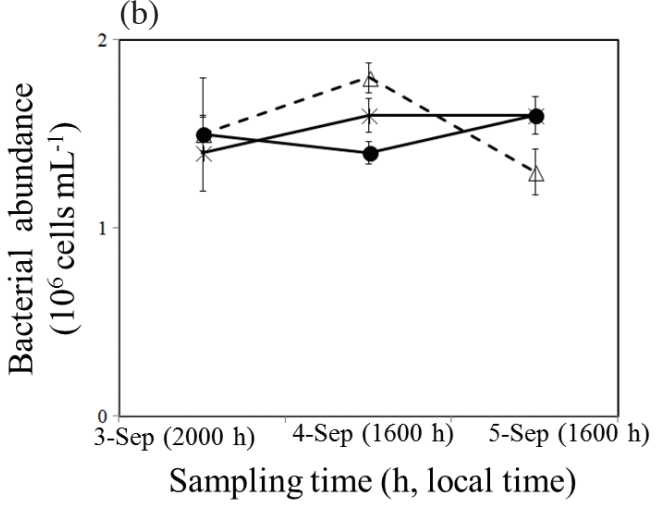

Fig. 3. Variations in Synechococcus spp. (a), bacterial (b), and viral (c) abundances of in situ seawater and VE-treated and VD-treated samples taken at 0 hour (3 September), 20 hours (4 September), and 44 hours ( 5 September) between $3-5$ September 2012. Error bars represent SD values. The filled black bar represents nighttime. 
(a)

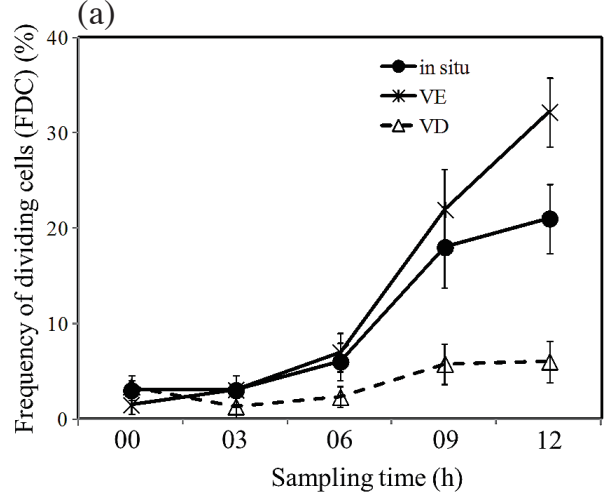

(b)

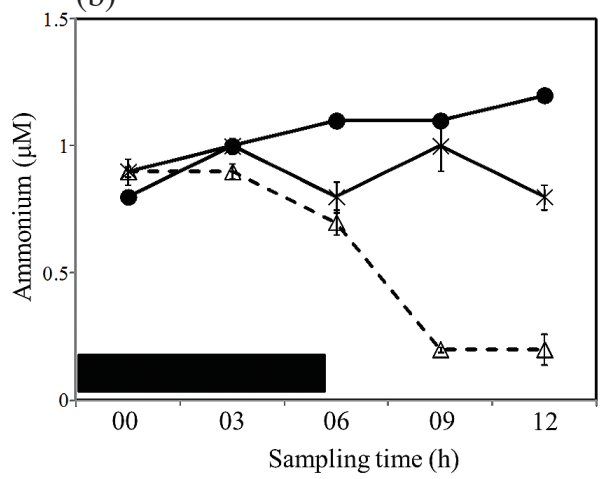

Fig. 4. Time-series of the frequency of dividing cells in Synechococcus spp. (a) and ammonium concentrations (b) of in situ seawater and virusexisting (VE) and virus-diluted samples (VD). Error bars represent SD values. The filled black bar represents nighttime.

(a)

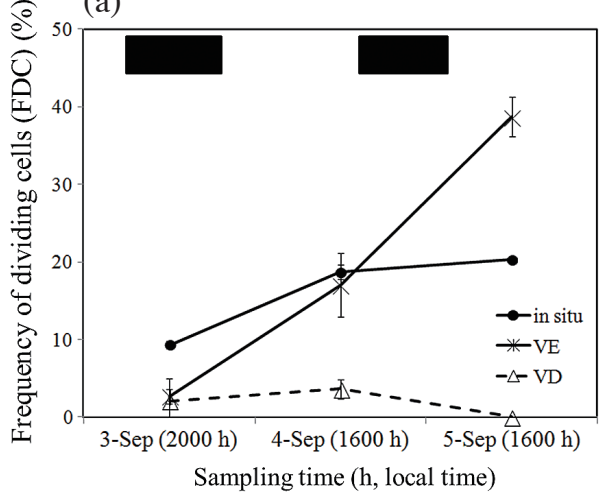

(b)

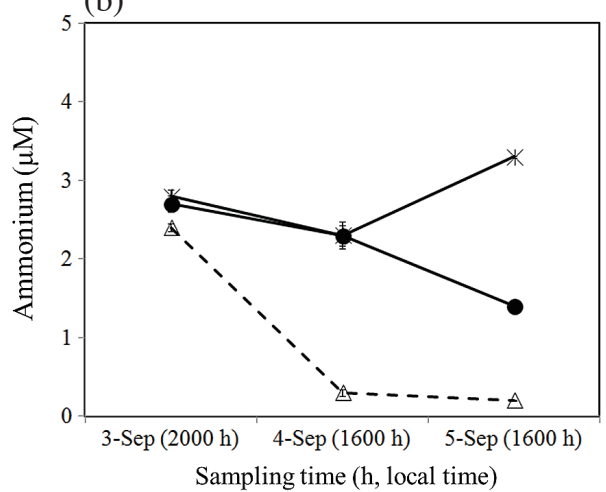

Fig. 5. Variations in the frequency of dividing cells in Synechococcus spp. (a) and ammonium concentrations (b) in in situ seawater and VE-treated and VD-treated samples taken at 0 hour (3 September), 20 hours (4 September), and 44 hours (5 September) between 3 - 5 September 2012. Error bars represent SD values. The filled black bar represents nighttime.

and the FDC of Synechococcus spp. in marine ecosystems.

In Exp. 1, although there was no significant difference in the original ammonium concentrations between $\mathrm{VE}$ and VD treatments at baseline ( $t$-test, $p<0.05)$ (Fig. 4b), there were significantly higher concentrations of ammonium in incubations containing untreated viruses than those containing highly diluted viruses at the end of the experiments ( $t$-test, $p<0.05$ ) (Fig. 4b). Furthermore, at the end of Exp. 2, ammonium concentrations were significantly higher in $\mathrm{VE}$ than VD treatments ( $t$-test, $p<0.05)$ (Fig. 5b).

\section{DISCUSSION}

This study found viral-induced ammonium regeneration resulted in increased growth and the proportion of dividing Synechococcus spp. cells. In our experiments VE treatment produced higher FDC values than VD after 12 hours incubation (28 - 37\% vs. 5 - 10\%) (Fig. 4a). In our experiments with an extended incubation time (44 hours), FDC remained high $(38.7 \%)$ in the VE treatment but not in the VD treatment (Fig. 5a). The most likely explanation for these results is that viral lysis releases nutrients that fuel the regrowth of Synechococcus spp.

Viruses are pervasive in marine environments, causing microbial mortality at a rate equaling that caused by grazing (Steward et al. 1996; Weinbauer and Höfle 1998; Wells and Deming 2006). Experimental studies show that although an increase in virus abundance can reduce growth rates in phytoplankton (Suttle et al. 1990), viral lysis can ultimately lead to higher phytoplankton productivity (Peduzzi and Weinbauer 1993). On the one hand these findings suggest that viral activity serves as a carbon sink; on the other hand they suggest it indirectly stimulates primary productivity and thus carbon production. Previous work in the same region suggests that diel fluctuations in Synechococcus spp. abundance results from differential consumption by nanoflagellates (Tsai et al. 2009). Tsai et al. (2012) also attributed significant Synechococcus spp. mortality at our study site to viruses and noted that the virus effect is greater at nighttime. Therefore, the abundance of Synechococcus spp. in Exp. 1 decreased as expected in the VE treatment and in the field over the first 6 hours (nighttime) (Fig. 2a). Similarly, there 
was a decrease in bacterial abundance during the night in the VE treatment with a concurrent slight increase in viral abundance and ammonium concentration (Figs. 2b, c, and 4b). One recent study concluded that the natural virus community, which stimulates the growth of Synechococcus spp., is essential for maintaining productivity (Weinbauer et al. 2011). Shelford et al. (2012), reported significant increases in the rates of viral-mediated ammonium regeneration in oligotrophic oceanic environments, suggesting that this viral activity supported phytoplankton production. At the end of all experiments in the present study the ammonium concentrations were found to be significantly higher in VE than in VD treatments, causing an increase in daytime FDC of Synechococcus spp.. Thus, our study supports the prevailing assumption that viral transformation of particulate organic matter (living cells) into dissolved compounds plays a significant role in nutrient recycling in the sea.

Lysis products are used by uninfected bacteria (Middelboe et al. 1996; Middelboe and Lyck 2002); therefore, viruses play an important role in recycling carbon within the bacterial community. This was verified experimentally by Middelboe and Lyck (2002) in a study in which viral activity stimulated carbon cycling by uninfected bacteria and reduced the accumulation of microbial biomass. We did not measure the concentration of DOM in the present study; however, our results show that the removal of viruses decreases bacterial abundance after 44 hours of incubation (Fig. 3b), supporting other studies in which lysis products stimulate growth in the non-infected community (Fuhrman 1999; Middelboe and Lyck 2002).

Nanoflagellates, on the other hand, may contribute to the release of DOM compounds that are rich in nutritional elements, including $\mathrm{N}, \mathrm{P}$, and $\mathrm{Fe}$, while grazing on bacteria (Noble and Fuhrman 1999; Selph et al. 2003; Poorvin et al. 2004). Although the contribution to nutrient regeneration by nanoflagellate grazers was excluded in our experiments by our use of $1.0 \mu \mathrm{m}$ filters to remove nanoflagellates in both treatments, we cannot preclude that all nanoflagellates were eliminated. It is uncertain whether smaller-sized nanoflagellates can graze on bacteria of the same size range, but it is unlikely that the small number of such tiny organisms would significantly change the results of this study. On the other hand, we expected that Synechococcus spp. abundance would be higher in the VE treatment than for in situ samples (Fig. 2a) because grazing should have been eliminated in the VE treatment. However, Synechococcus spp. abundance at the end of Exp. 2 exhibited no difference between the VE treatment and in situ samples (Fig. 3a). Interactions between viruses and grazers and their effects on picoplankton are probably very complex (Miki and Jacquet 2008) and might include various antagonistic or synergistic effects (Sime-Ngando and Ram 2005; Jacquet et al. 2007). For example, nanoflagellates can directly reduce viral abundance and infectivity through direct consumption of viruses or by grazing preferentially on viral-infected cells (Bettarel et al. 2005).

In conclusion, our results clearly show that up to $30 \%$ of Synechococcus spp. cells divide during VE treatment during the day, which was six times greater than in the VD treatment (about 5\%). At the end of these experiments there was a significantly higher concentration of ammonium in incubations containing natural abundances of viruses compared to those containing reduced viral abundance. We conclude that the natural virus community stimulates Synechococcus spp. growth and is essential for maintaining productivity in the ocean.

Acknowledgements This study was supported by a grant (NSC 101-2611-M-019-009) from the National Science Council, R.O.C.. We are most grateful to Messrs. James Steed and Buford Pruitt, Jr. for language editing and comments on the manuscript.

\section{REFERENCES}

Ayukai, T. 1996: Possible limitation of the dilution technique for estimating growth and grazing mortality rates of picoplanktonic cyanobacteria in oligotrophic tropical waters. J. Exp. Mar. Biol. Ecol., 198, 101-111, doi: 10.1016/0022-0981(95)00208-1. [Link]

Baudoux, A. C., M. J. W. Veldhuis, H. J. Witte, and C. P. D. Brussaard, 2007: Viruses as mortality agents of picophytoplankton in the deep chlorophyll maximum layer during IRONAGES III. Limnol. Oceanogr., 52, 2519-2529, doi: 10.4319/lo.2007.52.6.2519. [Link]

Baudoux, A. C., M. J. W. Veldhuis, A. A. M. Noordeloos, G. van Noort, and C. P. D. Brussaard, 2008: Estimates of virus- vs. grazing induced mortality of picophytoplankton in the North Sea during summer. Aquat. Microb. Ecol., 52, 69-82, doi: 10.3354/ame01207. [Link]

Bettarel, Y., T. Sime-Ngando, M. Bouvy, R. Arfi, and C. Amblard, 2005: Low consumption of virus-sized particles by heterotrophic nanoflagellates in two lakes of the French Massif Central. Aquat. Microb. Ecol., 39, 205-209, doi: 10.3354/ame039205. [Link]

Campbell, L. and E. J. Carpenter, 1986: Diel patterns of cell division in marine Synechococcus spp. (Cyanobacteria): Use of the frequency of dividing cells technique to measure growth rate. Mar. Ecol. Prog. Ser., 32, 139-148.

Carlsson, P. and D. A. Caron, 2001: Seasonal variation of phosphorus limitation of bacterial growth in a small lake. Limnol. Oceanogr., 46, 108-120, doi: 10.4319/ lo.2001.46.1.0108. [Link]

Chang, J., C. C. Chung, and G. C. Gong, 1996: Influences of cyclones on chlorophyll $a$ concentration and Synechococcus abundance in a subtropical western Pacific coastal ecosystem. Mar. Ecol. Prog. Ser., 140, 199205, doi: 10.3354/meps140199. [Link] 
Christaki, U., C. Courties, H. Karayanni, A. Giannakourou, C. Maravelias, K. Ar. Kormas, and P. Lebaron, 2002: Dynamic characteristics of Prochlorococcus and Synechococcus consumption by bacterivorous nanoflagellates. Microb. Ecol., 43, 341-352, doi: 10.1007/ s00248-002-2002-3. [Link]

Dolan, J. R. and K. Šimek, 1999: Diel periodicity in Synechococcus populations and grazing by heterotrophic nanoflagellates: Analysis of food vacuole contents. Limnol. Oceanogr., 44, 1565-1570, doi: 10.4319/ 1o.1999.44.6.1565. [Link]

Fuhrman, J. A., 1999: Marine viruses and their biogeochemical and ecological effects. Nature, 399, 541-548, doi: 10.1038/21119. [Link]

Haaber, J. and M. Middelboe, 2009: Viral lysis of Phaeocystis pouchetii: Implications for algal population dynamics and heterotrophic $\mathrm{C}, \mathrm{N}$ and $\mathrm{P}$ cycling. ISME J., 3, 430-441, doi: 10.1038/ismej.2008.125. [Link]

Hambly, E. and C. A. Suttle, 2005: The viriosphere, diversity, and genetic exchange within phage communities. Curr. Opin. Microbiol., 8, 444-450, doi: 10.1016/j. mib.2005.06.005. [Link]

Iriarte, A. and D. A. Purdie, 1994: Size distribution of chlorophyll $a$ biomass and primary production in a temperate estuary (Southampton Water): The contribution of photosynthetic picoplankton. Mar. Ecol. Prog. Ser., 115, 283-297.

Jacquet, S., I. Domaizon, S. Personnic, and T. Sime-Ngando, 2007: Do small grazers influence virus-induced mortality of bacteria in Lake Bourget (France)? Fund. Appl. Limnol., 170, 125-132, doi: 10.1127/18639135/2007/0170-0125. [Link]

Middelboe, M. and P. G. Lyck, 2002: Regeneration of dissolved organic matter by viral lysis in marine microbial communities. Aquat. Microb. Ecol., 27, 187-194, doi: 10.3354/ame027187. [Link]

Middelboe, M., N. O. G. Jørgensen, and N. Kroer, 1996: Effects of viruses on nutrient turnover and growth efficiency of noninfected marine bacterioplankton. Appl. Environ. Microbiol., 62, 1991-1997.

Miki, T. and S. Jacquet, 2008: Complex interactions in the microbial world: Underexplored key links between viruses, bacteria and protozoan grazers in aquatic environments. Aquat. Microb. Ecol., 51, 195-208, doi: 10.3354/ame01190. [Link]

Noble, R. T. and J. A. Fuhrman, 1998: Use of SYBR Green I for rapid epifluorescence counts of marine viruses and bacteria. Aquat. Microb. Ecol., 14, 113-118, doi: 10.3354/ame014113. [Link]

Noble, R. T. and J. A. Fuhrman, 1999: Breakdown and microbial uptake of marine viruses and other lysis products. Aquat. Microb. Ecol., 20, 1-11, doi: 10.3354/ ame020001. [Link]

Pai, S. C., Y. J. Tsau, and T. I. Yang, 2001: pH and buff- ering capacity problems involved in the determination of ammonia in saline water using the indophenol blue spectrophotometric method. Anal. Chim. Acta, 434, 209-216, doi: 10.1016/S0003-2670(01)00851-0. [Link]

Peduzzi, P. and M. G. Weinbauer, 1993: Effect of concentrating the virus-rich 2-200-nm size fraction of seawater on the formation of algal flocs (marine snow). Limnol. Oceanogr., 38, 1562-1565, doi: 10.4319/ lo.1993.38.7.1562. [Link]

Poorvin, L., J. M. Rinta-Kanto, D. A. Hutchins, and S. W. Wilhelm, 2004: Viral release of iron and its bioavailability to marine plankton. Limnol. Oceanogr., 49, 1734-1741, doi: 10.4319/lo.2004.49.5.1734. [Link]

Porter, K.G. and Y.S.Feig, 1980: The use of DAPI for identifying and counting aquatic microflora. Limnol. Oceanogr., 25, 943-948, doi: 10.4319/lo.1980.25.5.0943. [Link]

Selph, K. E., M. R. Landry, and E. A. Laws, 2003: Heterotrophic nanoflagellate enhancement of bacterial growth through nutrient remineralization in chemostat culture. Aquat. Microb. Ecol., 32, 23-37, doi: 10.3354/ ame032023. [Link]

Shelford, E. J., M. Middelboe, E. F. Møller, and C. A. Suttle, 2012: Virus-driven nitrogen cycling enhances phytoplankton growth. Aquat. Microb. Ecol., 66, 41-46, doi: 10.3354/ame01553. [Link]

Sime-Ngando, T. and A. S. P. Ram, 2005: Grazer effects on prokaryotes and viruses in a freshwater microcosm experiment. Aquat. Microb. Ecol., 41, 115-124, doi: 10.3354/ame041115. [Link]

Steward, G. F., D. C. Smith, and F. Azam, 1996: Abundance and production of bacteria and viruses in the Bering and Chukchi Seas. Mar. Ecol. Prog. Ser., 131, $287-$ 300, doi: 10.3354/meps131287. [Link]

Suttle, C. A. 2000: Cyanophages and their role in the ecology of cyanobacteria. In: Whitton, B. A. and M. Potts (Eds.), The Ecology of Cyanobacteria: Their Diversity in Time and Space, Springer Netherlands, Kluwer Academic Publishers, Boston, USA, 563-589, doi: 10.1007/0-306-46855-7_20. [Link]

Suttle, C. A., A. M. Chan, and M. T. Cottrell, 1990: Infection of phytoplankton by viruses and reduction of primary productivity. Nature, 347, 467-469, doi: 10.1038/347467a0. [Link]

Tsai, A. Y., K. P. Chiang, J. Chang, and G. C. Gong, 2005: Seasonal diel variations of picoplankton and nanoplankton in a subtropical western Pacific coastal ecosystem. Limnol. Oceanogr., 50, 1221-1231, doi: 10.4319/lo.2005.50.4.1221. [Link]

Tsai, A. Y., K. P. Chiang, J. Chang, and G. C. Gong, 2008: Seasonal variations in trophic dynamics of nanoflagellates and picoplankton in coastal waters of the western subtropical Pacific Ocean. Aquat. Microb. Ecol., 51, 
263-274, doi: 10.3354/ame01196. [Link]

Tsai, A. Y., W. M. Chin, and K. P. Chiang, 2009: Diel patterns of grazing by pigmented nanoflagellates on Synechococcus spp. in the coastal ecosystem of subtropical western Pacific. Hydrobiologia, 636, 249-256, doi: 10.1007/s 10750-009-9954-y. [Link]

Tsai, A. Y., G. C. Gong, R. W. Sanders, K. P. Chiang, J. K. Huang, and Y. F. Chan, 2012: Viral lysis and nanoflagellate grazing as factors controlling diel variations of Synechococcus spp. summer abundance in coastal waters of Taiwan. Aquat. Microb. Ecol., 66, 159-167, doi: 10.3354/ame01566. [Link]

Uysal, Z., 2006: Vertical distribution of marine cyanobacteria Synechococcus spp. in the Black, Marmara, Aegean, and eastern Mediterranean seas. Deep-Sea Res. Part IITop. Stud. Oceanogr., 53, 1976-1987, doi: 10.1016/j. dsr2.2006.03.016. [Link]

Wang, K. and F. Chen, 2004: Genetic diversity and population dynamics of cyanophage communities in the Chesapeake Bay. Aquat. Microb. Ecol., 34, 105-116, doi: 10.3354/ame034105. [Link]

Weinbauer, M. G. and M. G. Höfle, 1998: Significance of viral lysis and flagellate grazing as factors controlling bacterioplankton production in a eutrophic Lake. Appl. Environ. Microbiol., 64, 431-438.

Weinbauer, M. G., O. Bonilla-Findji, A. M. Chan, J. R. Dolan, S. M. Short, K. Šimek, S. W. Wilhelm, and C. A. Suttle, 2011: Synechococcus growth in the ocean may depend on the lysis of heterotrophic bacteria. $J$. Plankton Res., 33, 1465-1476, doi: 10.1093/plankt/ fbr041. [Link]

Wells, L. E. and J. W. Deming, 2006: Significance of bacterivory and viral lysis in bottom waters of Franklin Bay, Canadian Arctic, during winter. Aquat. Microb. Ecol., 43, 209-221, doi: 10.3354/ame043209. [Link]

Wilhelm, S. W., S. M. Brigden, and C. A. Suttle, 2002: A dilution technique for the direct measurement of viral production: A comparison in stratified and tidally mixed coastal waters. Microb. Ecol., 43, 168-173.

Worden, A. Z., J. K. Nolan, and B. Palenik, 2004: Assessing the dynamics and ecology of marine picophytoplankton: The importance of the eukaryotic component. Limnol. Oceanogr., 49, 168-179, doi: 10.4319/ lo.2004.49.1.0168. [Link] 